This manuscript is a preprint and has been submitted for publication in Sedimentary Geology. The manuscript has undergone peer-review, but subsequent versions of this manuscript may have different content. Please feel free to contact the first author directly regarding the manuscript. (brian.burnham@abdn.ac.uk) 


\title{
Discriminating stacked distributary channel from palaeovalley fill sand bodies in foreland basin settings
}

\author{
Brian S. Burnham ${ }^{\mathrm{a}, \mathrm{b}}$, Rhodri M. Jerrett ${ }^{\mathrm{a}}$, David Hodgetts ${ }^{\mathrm{a}}$, Stephen S. Flint ${ }^{\mathrm{a}}$ \\ ${ }^{a}$ Department of Earth and Environmental Sciences, University of Manchester, Manchester M13 9PL, UK \\ ${ }^{b}$ School of Geosciences, Department of Geology and Geophysics, University of Aberdeen, Aberdeen AB24 $3 U E$, \\ $U K$
}

\begin{abstract}
Stacked fluvial distributary channel deposits and palaeovalley fills can form major, multi-storey sand bodies with similar thicknesses, and with lateral extents often greater than a single exposure. Consequently, they can be difficult to tell apart from one another using outcrop data. This study addresses this problem by quantitatively analysing the architecture of five stacked fluvial distributary channel deposits and two palaeovalley fills from the Pennsylvanian Pikeville and Hyden formations of the central Appalachian Basin, USA. The a priori interpretation of the sand bodies as stacked distributary channels and palaeovalley fills is possible because a robust in-place coal seam correlation framework allows for the recognition of different basin-scale architectures for each type - aspect ratios $<1000$ and envelopes of fluvial and deltaic strata for stacked distributary channels, and aspect ratios $>1000$ and a regional basinward facies shift at the bases of palaeovalley fills. Sand body thickness, storey thickness, position and length of storey contacts within the sand body are similar in both types. However, they can be distinguished by different up-system to down-system changes in their respective architectures. Stacked distributary channel sand bodies thin down system, display a decrease in storey thickness, an increase in the mean position of storey heights in the sand body and a decrease in the length of storey contacts. These trends are the result of down-system decrease in channel size, and confinement associated with radially distributive fluvial systems. Palaeovalley fill sand bodies thicken down-system, display an increase in storey thickness, a decrease in the mean position of storey heights, and a decrease in the length of storey contacts. The increase in sand body and storey thickness are the result of down-system increases in original channel size, consistent with trunk axial fluvial systems fed by tributaries that predominate during valley-formation. The downsystem increase in amalgamation reflects a down-system decrease in accommodation, from the higher subsidence rate active margin of the basin, and is therefore not necessarily characteristic of palaeovalley fill architectures in all basin settings. This study emphasises the requirement for detailed correlation work and quantitative analysis of external and internal architectures before the interpretation of sand bodies as stacked distributary channels or palaeovalley fills.
\end{abstract}

Keywords: 3D outcrop modelling, lidar, quantitative characterisation, Distributive Fluvial System, palaeovalley, foreland basin 


\section{Introduction}

Major fluvial sand bodies which may be successions of stacked distributary channels (Hirst, 1992; Nichols and Fisher, 2007; Kukulski et al., 2013) or palaeovalley fills (e.g. Jennette et al., 1991; Hampson et al., 1999; Wu and Bhattacharya, 2015) have been the subject of extensive research because of their hydrocarbon reservoir potential. The difference between these two types of sand body is critical to the accurate prediction of reservoir geometry, for the correct reconstruction of palaeogeography, and sequence stratigraphic analysis. A challenge when discriminating between palaeovalley fills and stacked distributary channels at outcrop scales, is that the lateral extent of both sand body types commonly exceeds that of the exposure, and their respective thicknesses may be similar. Additionally, many incised valleys do not display a "basinward facies shift" at their base (Blum et al., 2013; Holbrook and Bhattacharya, 2012) - a key criterion historically used to identify palaeovalley fills (e.g. Posamentier and Vail, 1988; Van Wagoner et al., 1988, 1990). Recent studies of modern, active fluvial systems have shown that in plan view distributary fluvial channels bifurcate, and individual channel size decreases down-system (Hartley et al., 2010; Weissmann et al., 2010). By comparison, palaeovalleys are characterised by one axial fluvial system with a tendency for tributaries to converge into a major channel down-system (Blum et al., 2013). Therefore, in the stratigraphic record, the height of fully preserved storeys and thickness of the composite sand body should decrease down-system in stacked distributary channels. In palaeovalley fills, the opposite should be true: the thickness of fully preserved storeys and the thickness of the composite sand body should increase down-system. This criterion has been applied to the rock record to interpret distributive fluvial systems (Nichols and Fisher, 2007; Owen et al., 2015; Weissmann et al., 2013), but has not been rigorously applied as a means of recognising palaeovalley fills (c.f. Jerrett et al., 2017). In successions that contain both stacked distributary channels and palaeovalley fills, basin-wide up-dip to down-dip statistical trends in sand body size and preserved storey thickness may not be clear. To complicate matters further, full storey thicknesses are commonly not preserved within the sand bodies due to top-truncation by younger storeys, rendering palaeohydraulic analysis difficult. Nevertheless, the interpretation of fluvial sand bodies as either stacked distributary channels or palaeovalley fills should be possible via a detailed, quantitative analysis of the internal architecture and geometry of the sand body.

The majority of naturally-occurring rock exposures are markedly two dimensional (e.g., elongate coastal cliffs and road-cut exposures), presenting difficulties for the extraction of plan view data, and reconstruction of fluvial style. However, advances over the past two decades in data collection, processing and analysis techniques have allowed for the quantitative description of the geostatistical properties of exposed successions, using three-dimensional (3D) digital outcrop models (DOMs) (Bellian et al., 2005; Buckley et al., 2008; Fabuel-Perez et al., 2010; Olariu et al., 2011; Hodgetts, 2013; Rarity et al., 2014; Burnham and Hodgetts, 2019). In this study, these digital geospatial and remote sensing approaches (i.e., lidar integration with coaxially aligned photography and differential geospatial navigation satellite system (DGNSS) measurements) have been applied to a succession of fluvial sand bodies from the Upper Carboniferous (Pennsylvanian) Breathitt Group of the central Appalachian Basin, USA (Fig. 1). The upper Breathitt Group contains fluvial sand bodies that are interpreted as progradational stacked distributary channels (Jerrett et al., 2017), and others that unequivocally represent palaeovalley fills, marked at their bases by regional basinward facies shifts of fluvial onto marine rocks (Aitken and Flint, 1994, 1995; Jerrett et al., 2017). The Breathitt Group therefore represents an ideal case study to achieve the key aims of this study. These are: (1) to quantitatively describe, and compare the architecture of stacked distributary channel and palaeovalley fill sand bodies, (2) determine principal depositional controls the resulting architectures, and (3) delineate criteria for the recognition of stacked distributary channels versus palaeovalley fills, from limited outcrop and subcrop data. 


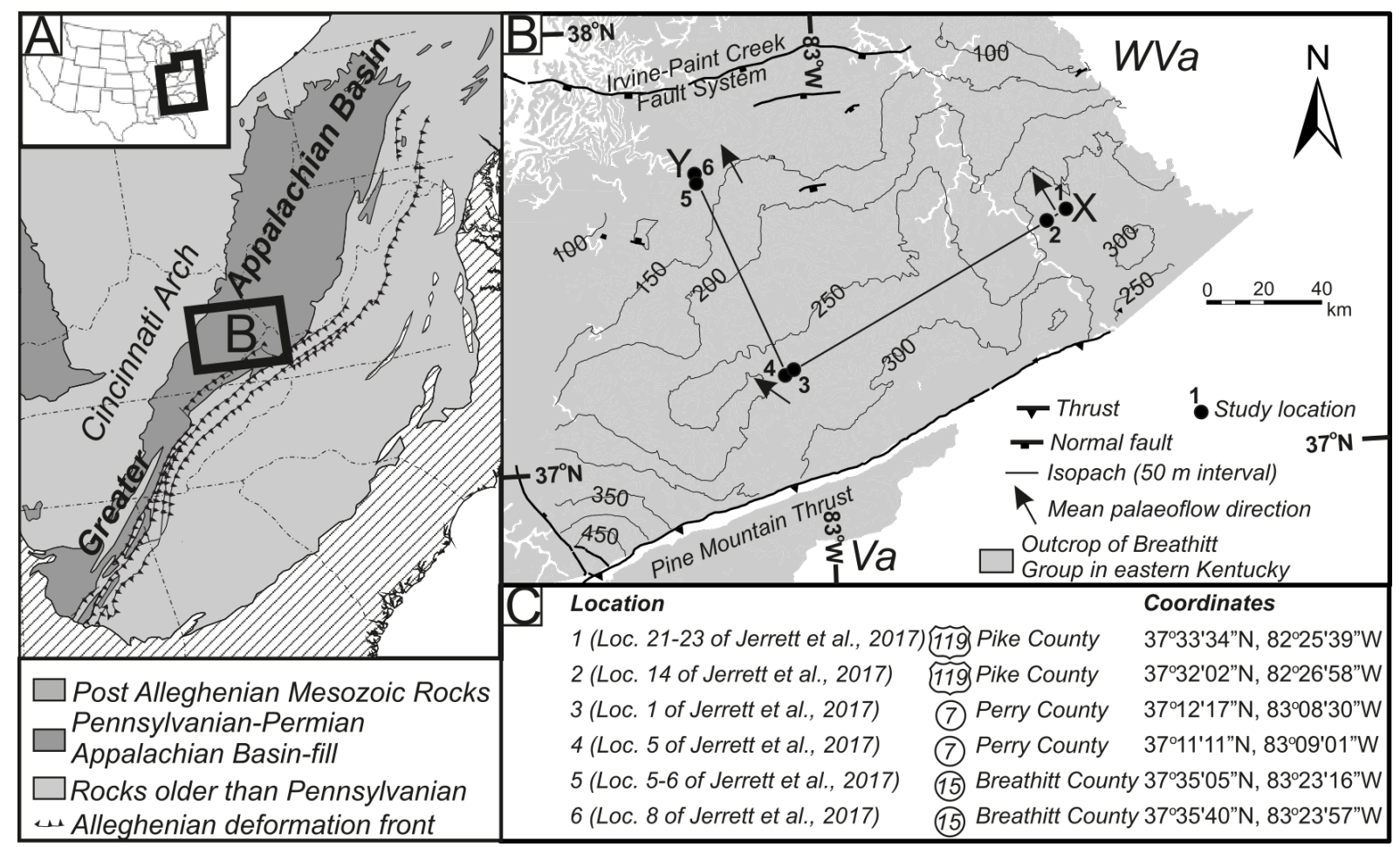

Figure 1: (A) Location of the study area in the contiguous USA and within the greater Appalachian Basin. (B) Geological map of eastern Kentucky, showing the location of the six road cuts which were targeted for study. Isopach lines of the combined thickness of the Pikeville and Hyden formations is shown, as well as vector mean palaeoflow measurements from the Pikeville and Hyden Formations (from Jerrett et al., 2017). Line of section $\mathrm{X}-\mathrm{Y}$ in Figure 3 shown. (C) Location details of the six road cuts targeted for study. Abbreviations: Loc. = Location; Va $=$ Virginia; WVa $=$ West Virgina. 


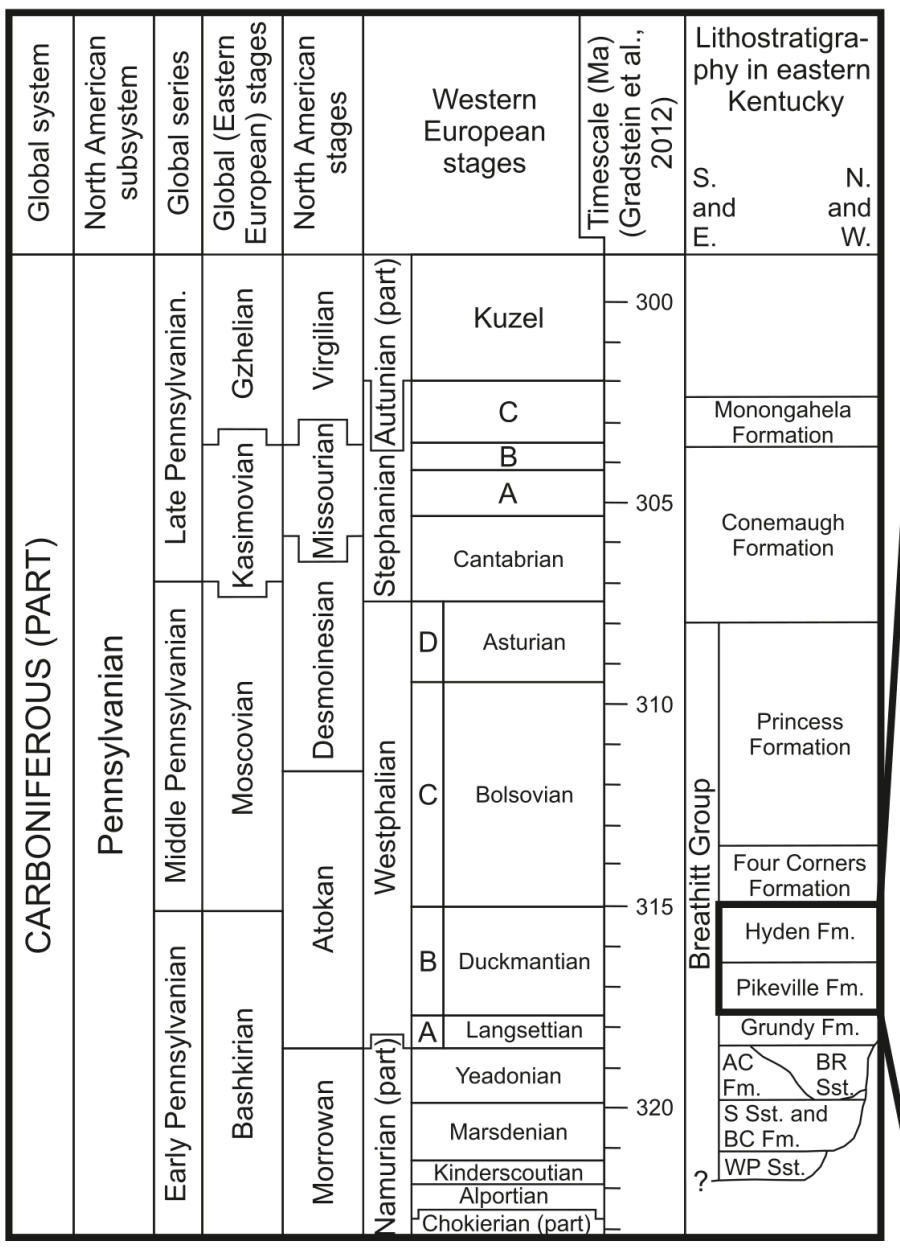

B

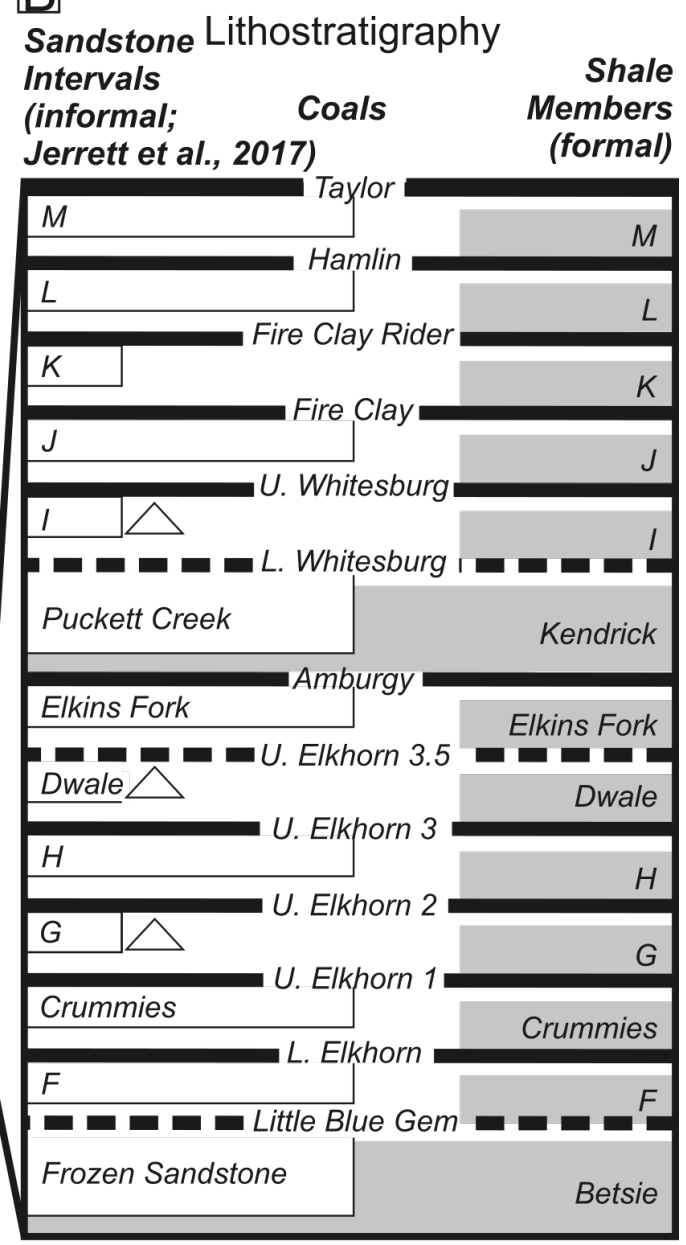

Figure 2: (A) Chronostratigraphy and lithostratigraphy of the Alleghanian foreland basin fill of the central Appalachian Basin in eastern Kentucky. Based on data from Greb et al. (2008), but recalibrated to the timescale of (Gradstein et al., 2012). Abbreviations: AC Fm. = Alvy Creek Formation; BC Fm. = Bottom Creek Formation; BR Sst. = Bee Rock Sandstone; WP Sst. = Warren Point Sandstone; S Sst. = Sewanee Sandstone. (B) Named coals, marine to marginal-marine shale members and fluvio-estuarine sandstone intervals in the Pikeville and Hyden formations (from Jerrett et al., 2017). Not all coals are shown, and dashed lines represent more locally developed coals (cf. Rice and Hiett, 1994). More locally developed shale members, or those with equivocal evidence for deposition in fully marine conditions are shown in hatched grey. Width of speckled boxes corresponds to the basinward extent of the sandstone interval. These fluvio-estuarine sandstone intervals are the object of this study.

that can exceed $10 \mathrm{~km}$ wide, and are up to $40 \mathrm{~m}$ thick (Fig. 2b). Jerrett et al. (2017) noted that fluvial sand bodies incised into marine strata (regional basinward shifts in facies) also have aspect ratios greater than 1000, and that these represent palaeovalley fills. By contrast, sand bodies that show no basinward facies shifts anywhere in the basin have aspect ratios that are typically less than 1000. Jerrett et al. (2017) recognised that these sand bodies thin, or become absent down-system, and reasoned that they represent stacked successions of distributary channels which had distributed their sediment load across an aggrading delta plain. These authors also recognised an intermediate type of sand body with no evidence for a basinward facies shift updip, but do display a basinward shift in facies down-dip. These bodies have been interpreted as stacked distributary channels in the up-dip high accommodation orogenic part of the basin, but pass down-dip into palaeovalleys towards the more degradational, lower accommodation cratonic margin of the foreland basin. These sand bodies display intermediate aspect ratios to the two other types of multi storey fluvial sand bodies (Jerrett et al., 2017) and are not targeted for analysis in this study. All sand body types are extensively exposed in a series of road cuts constructed throughout eastern Kentucky since the 1970s (e.g. Horne et al., 1978; Chesnut Jr, 1994; Aitken and Flint, 1995; Jerrett et al., 2017). Road cuts provided exposures up to 200 
$\mathrm{m}$ high and $1 \mathrm{~km}$ long, but compared to the width of many of the sand bodies, irrespective of genetic type, they are often too short to provide complete cross sections through the sand bodies, capturing their complete external geometries and internal architecture. A robust in-place coal seam correlation framework for the Breathitt Group (Rice and Hiett, 1994) allows sand bodies to be confidently correlated from road-cut to road-cut across the basin, and lateral changes in external and internal architecture within the same sand body to be assessed.

The Pikeville and Hyden formations of the upper Breathitt Group are the targets of this study (Fig. 2). In outcrop, they contain major transversely oriented multistorey fluvial sand bodies that can exceed $10 \mathrm{~km}$ wide, and are up to $40 \mathrm{~m}$ thick (Fig. 2b). Individual storeys can exceed $10 \mathrm{~m}$ thickness, and are characterised by an erosional base overlain by a finingand thinning-upward succession dominated by trough cross bedded sandstone. However, their bases are commonly lined with pebble-sized siderite clasts and peat rafts, now preserved as coal, and their upper parts (if preserved) typically contain ripple cross laminated sandstone, and mudstone. Architecturally, individual storeys are organised into a continuum between (i) multiple fining- and thinning-upward bedsets up to $5 \mathrm{~m}$ thick, that display variable amounts of incision into one another, and complex cross-cutting relationships, and (ii) large-scale inclined bedsets (that dip by up to 15o), that extend from the base to the top of the storey, and fine upward from sandstone-dominated to heterolith dominated up the inclined surface (Aitken and Flint, 1994, 1995; Martino, 1996; Jerrett et al., 2017). The former are interpreted as channels containing down-stream, laterally and obliquely accreting mid-channel bars, whereas the latter are interpreted as single-thread channels, migrating via the accretion of point-bars (Jerrett et al., 2017). A minority of storeys are represented by simple basal concave-up surfaces (either erosional, or representing an older topographic surface), that are passively onlapped by trough cross bedded or ripple cross laminated sandstone, flaser or lenticular bedded heterolith, or shale (Greb and Chesnut Jr, 1992; Aitken and Flint, 1994, 1995; Jerrett et al., 2017). Although predominantly interpreted as fluvial in origin, numerous workers have recognised the presence of marine ichnogenera, within some storeys, especially fine-grained successions that onlap the simple concave-up channel fills (e.g. Greb and Chesnut Jr, 1992; Jerrett et al., 2017). Additionally, carbonaceous drapes on cross bed foresets, reversed palaeoflow readings, lenticular and flaser bedding have been interpreted as tidal influence on fluvial flow in the lower reaches of some of the palaeochannels (Greb and Chesnut Jr, 1992; Aitken and Flint, 1995; Martino, 1996; Jerrett et al., 2017). Consequently, the role of backwater processes cannot be discounted as influencing stacking patterns in these successions.

Regional mapping by Jerrett et al. (2017) showed that fluvial, multi-storey sand bodies incised into marine strata (regional basinward shifts in facies) also have aspect ratios greater than 1000, and that these represent palaeovalley fills. Some of these palaeovalleys extend from the preserved orogenic to cratonic margin of the basin. Jerrett et al. (2017) interpreted these as the products of the largest eustatic sea-level falls that were capable of outpacing tectonic subsidence even in the most subsident parts of the preserved basin. Therefore, the preserved basin (and study area) can be considered to be wholly within the "low accommodation" "Zone B" in Posamentier and Allen (1993) study of the influence of subsidence patterns on stratigraphic stacking patterns. By contrast Jerrett et al. (2017) demonstrated that sand bodies that show no basinward facies shifts anywhere in the basin have aspect ratios that are typically less than 1000. Jerrett et al. (2017) recognised that these sand bodies thin, or become absent downsystem, and reasoned that they represent stacked successions of distributary channels which had distributed their sediment load across an aggrading delta plain. These authors also recognised an intermediate type of sand body with no evidence for a basinward facies shift up-dip, but that do display a basinward shift in facies down-dip. These bodies have been interpreted as stacked distributary channels in the up-dip higher accommodation orogenic part of the basin, but pass down-dip into palaeovalleys towards the more degradational, lower accommodation cratonic margin of the foreland basin. These sand bodies display intermediate aspect ratios to the two other types of multistorey fluvial sand bodies (Jerrett et al., 2017) and are not targeted for analysis in this study. All sand body types are extensively exposed in a series of road cuts 
constructed throughout eastern Kentucky since the 1970s (e.g. Horne et al., 1978; Chesnut Jr, 1994; Aitken and Flint, 1994; Jerrett et al., 2017). Road cuts provided exposures up to 200 $\mathrm{m}$ high and $1 \mathrm{~km}$ long, but compared to the width of many of the sand bodies, irrespective of genetic type, they are often too short to provide complete cross sections through the sand bodies, capturing their complete external geometries and internal architecture. A robust in-place coal seam correlation framework for the Breathitt Group (Rice and Hiett, 1994) allows sand bodies to be confidently correlated from road-cut to road-cut across the basin, and lateral changes in external and internal architecture within the same sand body to be assessed (Fig. 2b).

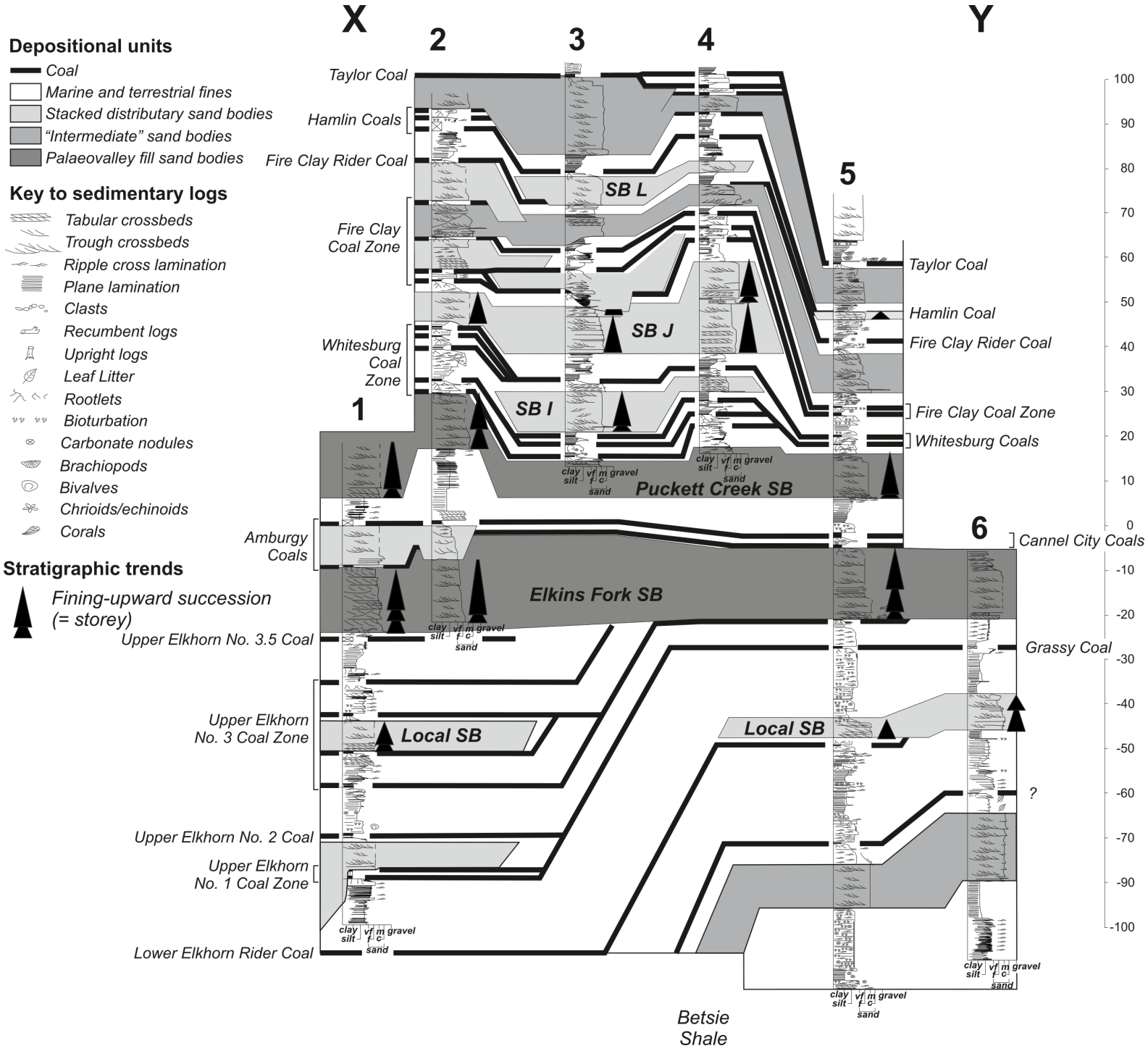

Figure 3: Correlated cross section showing sedimentary logs collected at locations 1-6. The line of section $\mathrm{X}-\mathrm{Y}$ is shown of Fig. 1. Only the sand bodies characterised in this study are labelled. The locations where quantitative data were collected from these sand bodies are denoted by black triangles representing the positions of storeys within the sandstone bodies, where the sedimentary log was collected.

\section{Methods}

\subsection{Site selection}

Five stacked distributary channel sand bodies, and two palaeovalley fill sand bodies in the Pikeville and Hyden Formations were targeted for study at 6 locations (Fig. 1). Two of the locations are along U.S. Route 119 (US 119) between Hazard and Williamson, Pike County (Locations 1 and 2), two along Kentucky Route 7 (Ky 7) south of Hazard, Perry County (Locations 3 and 4), and two along Kentucky Route 15 (Ky 15) north of Jackson, Breathitt County 
(Locations 5 and 6; Fig. 1). Road cuts along US 119 and Ky 7 expose the Pikeville and Hyden Formations approximately $40 \mathrm{~km}$ down depositional dip from the preserved erosional margin of the basin to the SE, whereas the exposures along Ky 15 exhibit the same stratigraphy another $80 \mathrm{~km}$ down depositional dip towards the NW (Fig. 1). The sites were selected because they expose the same (i.e., stratigraphically equivalent) sand bodies, which could therefore be compared for up-to-down system differences in architecture (Fig. 3). The analysed road cuts along Ky 7 are single-sided (i.e., there is exposure on just one side of the road), whereas the road cuts along US 119 and Ky 15 are double-sided.

The stacked distributary sand bodies targeted were (a) a locally-developed unnamed sand body below the Grassy Coal (at Locations 5 and 6), (b) a locally-developed unnamed sand body in the Upper Elkhorn No. 3 Coal Zone (at Location 1), (c) Sand Body I (at Location 3), (d) Sand Body J (at Locations 2, 3 and 4), and (e) Sand Body L (at Location 5). The palaeovalley fill sand bodies targeted were the Elkins Fork Sand Body (at Locations 1, 2 and 5), and the Puckett Creek Sand Body (also at Locations 1, 2 and 5). This information is summarised in Table 1.

\subsection{Data acquistion}

The stratigraphy containing all targeted sand bodies at all six road cut locations was logged at bed-scale, recording the full range of lithologies, grain sizes, sedimentary structures, trace and body fossils. Then, a Riegl LMS-Z420i terrestrial laser scanner (TLS) was used to acquire highresolution point cloud datasets from a total swathe of each road cut. Data were collected from exposures on both sides of the double-sided road cut at Locations 5 and 6 and from the single side road cuts at Locations 1 and 2. Each point cloud contains a detailed 3D representation of the exposures at a data point spacing of $0.05 \mathrm{~m}(\sim 0.10-0.20 \mathrm{~m})$ geometric resolution. The position of each TLS location was chosen to capture as much of the exposure as possible, eliminating any shadows or gaps within the data. Sub-metre DGNSS measurements were acquired for each position to align them to one another at each locality, and into real world coordinates. A DSLR camera was coaxially mounted on top of the scanner and used to photograph (termed "onscanner" images) the same scanned scenery, registered to its associated point cloud, creating an accurate pixel-point-ratio of the datasets. Composite centimetre-scale sedimentary logs were measured through the exposed stratigraphy in all six measured road cuts, providing facies and palaeocurrent azimuth data, which were integrated into the finalised DOMs.

\subsection{Data processing}

Multiple software resources were used to collate, process, align and geoposition the acquired data (outlined in Pringle et al., 2004; Hodgetts, 2013; Rarity et al., 2014) to produce the DOMs. Each scan location position was exported into Innovmetric: PolyworksTM and integrated with their associated DGNSS measurement. The alignment matrix produced from this process was imported into the scan project for each locality, giving each scan location a real world coordinate position. Additionally, composite sedimentary logs were correlated and key stratigraphic and architectural contacts were used to spatially define the sand bodies analysed herein.

\subsection{Data visualisation}

Once these data were collated together, a software package created at The University of Manchester, Virtual Reality Geological Studio (VRGS) (Hodgetts et al., 2007), was used for visualisation and analysis of high resolution, spatially accurate 3D representations of the road-cut exposures (techniques outlined by van Lanen et al., 2009; Fabuel-Perez et al., 2010). The visualisation method used for this study involved a photorealistic approach of colourising both point cloud and surface mesh realisations from the RGB information from the on-scanner images, creating a 3D photorealistic model of the scanned outcrops (Fig. 4a). A detailed description of the photorealistic method applied to the models is discussed in Bellian et al. (2005); Pringle et al. (2006); Fabuel-Perez et al. (2010) has been adapted for this study. These models allow for identification of stratigraphic contacts and stratal architecture from the data visible only in the RGB information. 

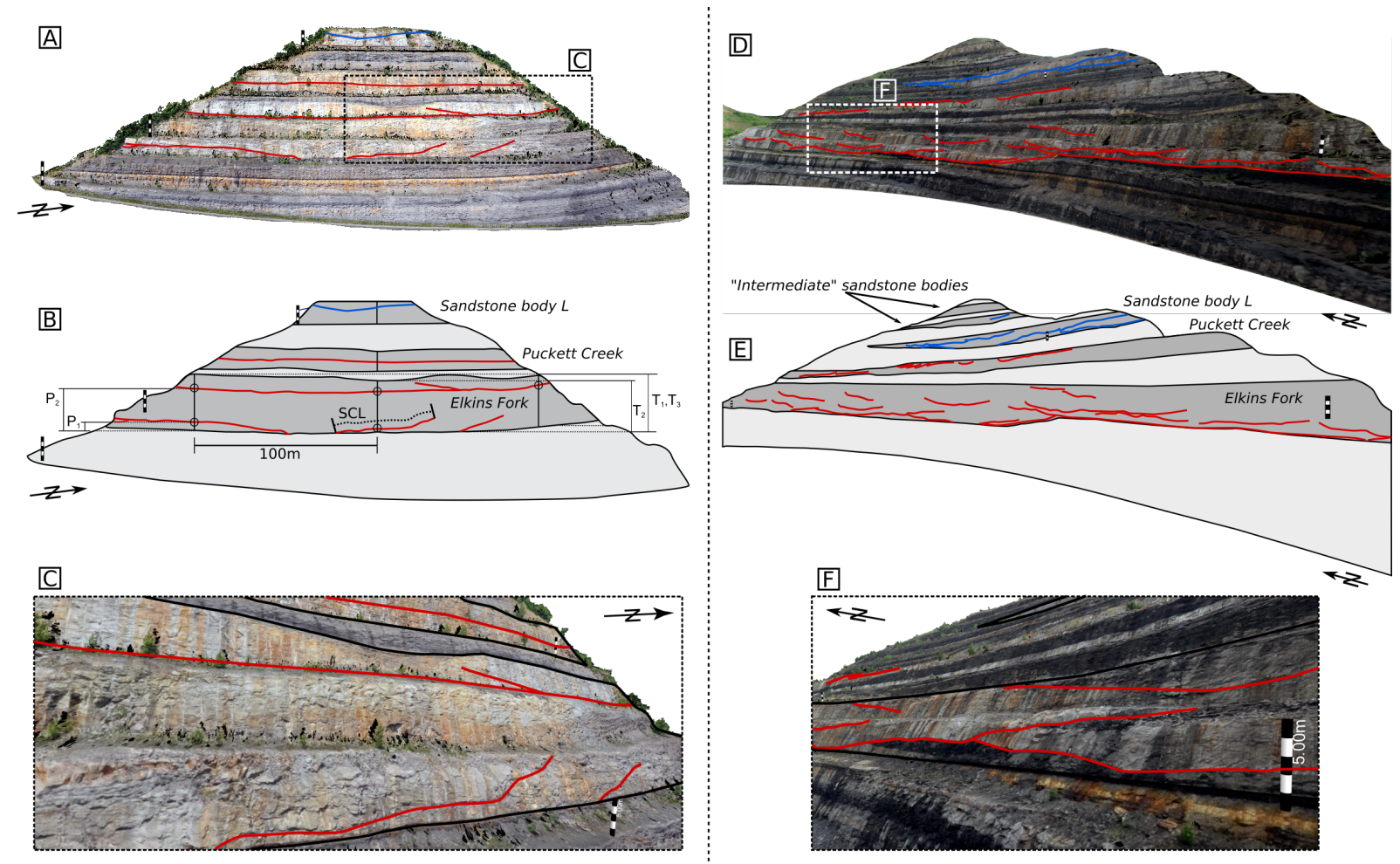

Figure 4: (A) Example of a photorealistic DOMbuilt fromintegration of lidar, co-axiallymounted photographic and DGNSS data illustrating a road cut at Loc. 5 (KY 15). (B) Illustration of how the architectural metricswere collected in each sand body. Sand bodies are dark greywith the internal storeys digitised in blue (stacked distributaries) and red (palaeovalleys) lines. Storey contact length (SCL), sand body thickness (T) and position of storey contact from base of sand body $(\mathrm{P})$ are labelled accordingly. $\mathrm{T}$ and $\mathrm{P}$ are measured from a vertical line drawn every $100 \mathrm{~m}$ lateral distance (denoted by thick black lines) irrespective of the length of the exposure. (C) Detailed view of a 3D DOM used in the analysis with storey contacts demarcated (red) and the analysed sand bodies outlined (black). (D) Example photorealistic DOM of the same location (Loc. 5) as (A) but on the opposite side (East) of the road. This illustrates the spatial and dimensional difference of the outcrops (West lateral $=225 \mathrm{~m}$, vertical height $=82 \mathrm{~m}$; East - lateral distance $=540 \mathrm{~m}$, vertical height $=290 \mathrm{~m})$ and the size variability of these road cut exposures. (E) Similar illustration as (B) to show sand body dimensions and storey contacts that are analysed in this study site. (F) Detailed view of the 3D DOM for the exposure opposite of (A) used for analysis with storey contacts demarcated (red) and the sand bodies outlined (black). All features were interpreted in VRGS with $0.20 \mathrm{~m}$ spatial accuracy. Note - scale bar is $5 \mathrm{~m}$

\subsection{Characterisation of sand body architecture from $3 D$ digital outcrop models}

In this study, a sand body is referred to as a succession of sandstone channel fill elements bounded by muddy units, irrespective of their genetic origin (i.e., stacked distributary or palaeovalley fill). Individual storeys are defined according to Friend et al. (1979) and Bridge and Tye (2000) (Fig. 4b). The analytical toolset available within VRGS was used to interpret the DOMs. Sand body geometries were quantitatively described using: (a) the Polyline tool, which was used to digitise storey contacts in the three-dimensional space (Figure 4), from which the length and approximate spatial position of storey contacts could be extracted (Table 1); (b) the Geo Polygon tool, used to digitise a 3D polygon around each sand body, into which facies and palaeocurrent data from the sedimentary logs could be integrated, and from which the cross-sectional areas of the sand bodies could be calculated; and (c) thickness measurements were recorded by creation of 3D vertical measurements (Fig. 4b) throughout each sand body unit across the outcrops at $100 \mathrm{~m}$ spacing in order to reduce bias where only parts of storeys are laterally preserved. 


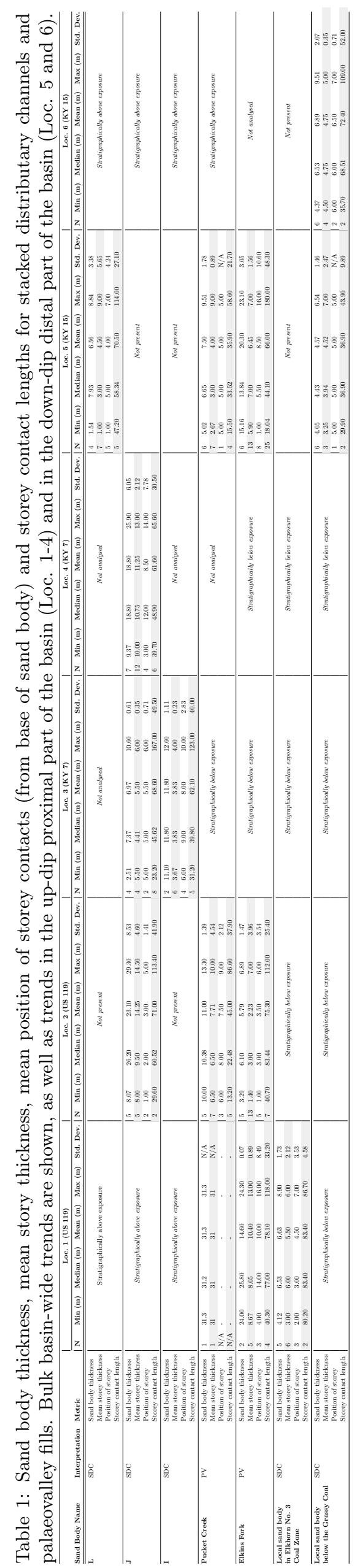


From these data the external architecture (sand body thickness) of individual sand units was calculated. The mean storey thickness within each sand body was calculated. The maximum storey thickness approximately reflects the (undecompacted) thalweg depth of channels. However, most storeys within sand bodies are truncated at their tops by incision from overlying storeys, so the storey thicknesses presented represent the minimum channel depth. The position of storey contacts relative to the base of each sand body was calculated, and used as a proxy for the degree of storey preservation within each sand body (i.e., more storey contacts close to the base of the sand body may be representative of significant erosion, and/or non-preservation of earlier storeys, whereas storey contacts evenly distributed throughout the sand body may be indicative of the more even preservation of storeys during deposition of the sand body). Finally, the average length of individual storey contacts were calculated from the individual storey contacts digitised and measured in each sand body. A major limitation is that, as noted by Jerrett et al. (2017), many storey contacts cannot be reliably traced across the entirety of the exposure. This is largely due to vegetation, masking storey contacts, or because sand-on-sand contacts across storey boundaries obscure those storey contacts. Within the confines of these limitations, however, individual storey contact lengths were used, and with it the number of clear discernible storeys within each sand body, as a proxy for amalgamation of the sand body.

\section{Results and discussion}

The minimum, median, mean and maximum of each metric for the sand body thickness, mean storey thickness, mean position of storeys relative to the base of the sand body, and mean length of storey contacts for each measured sand body is provided in Table 1. A summary form of the data organised according to whether the sand body was interpreted by Jerrett et al. (2017) as a succession of stacked distributary channels or a palaeovalley is provided in Table 2 and illustrated in Figures 5 and 6.

\subsection{Comparison of stacked distributary channels and palaeovalley fills}

Stacked distributary channel sand bodies are on average $10.7 \mathrm{~m}$ thick $(\mathrm{SD}=6.8, \mathrm{n}=39)$. The average thickness of their channel storeys is $6.8 \mathrm{~m}(\mathrm{SD}=2.4, \mathrm{n}=47)$, the mean position of storey contacts inside the sand body is $5.6 \mathrm{~m}$ from the base of the sand body ( $\mathrm{SD}=3.5, \mathrm{n}=$ $23)$, and the mean length of internal storey contacts is $65.8 \mathrm{~m}(\mathrm{SD}=41.0, \mathrm{n}=32)$ (Table 2). Palaeovalley fills are on average $11.8 \mathrm{~m}$ thick $(\mathrm{SD}=6.8, \mathrm{n}=24)$. The average thickness of their channel storeys is $7.0 \mathrm{~m}(\mathrm{SD}=3.2, \mathrm{n}=35)$, the mean position of storey contacts inside the sand body is $6.9 \mathrm{~m}$ from the base of the sand body $(\mathrm{SD}=4.6, \mathrm{n}=20)$, and the mean length of internal storey contacts is $60.1 \mathrm{~m}(\mathrm{SD}=40.3, \mathrm{n}=45)$ (Table 2). The standard deviation of these data demonstrate the large overlap in these metrics between the two types of sand body and therefore the limitations of using such data for discrimination between them.

It is possible to compare the same metrics between what we term the "up-dip domain" (Locations 1-4, closer to the orogenic margin, and to the input point of the rivers into the basin) and the "down-dip domain" (Locations 5 and 6, which are closer to the cratonic margin of the basin and further from the input point of the rivers into the basin). The up-dip domain is also an area of higher accommodation than the down-dip domain, and we purposefully use the terms "higher" accommodation and "lower" accommodation" (rather than "high" and "low") because the study is entirely located within the "low accommodation" Zone B of Posamentier and Allen (1993). Isopach maps for the combined Pikeville and Hyden formations (Fig. 1b) suggest that accommodation rates were roughly double at higher accommodation Locations 1-4, compared to lower accommodation Locations 5 and 6 . In the higher accommodation up-dip domain, stacked distributary channel sand bodies are, on average, thicker than palaeovalley fills (13.5 $\mathrm{m}$ versus $10.5 \mathrm{~m} ; \mathrm{n}=23, \mathrm{n}=12)$. However, average storey thickness, $(7.0 \mathrm{~m}$ in stacked distributary channels, versus $6.8 \mathrm{~m}$ in palaeovalley fills; $\mathrm{n}=33, \mathrm{n}=8$ ), mean position of storey from the base of the sand body $(3.4 \mathrm{~m}$ in stacked distributary channels, versus $7.0 \mathrm{~m}$ in palaeovalley fills; $\mathrm{n}=15, \mathrm{n}=9$ ), and the length of storey contacts (69.3 $\mathrm{m}$ in stacked distributary channels, versus $66.1 \mathrm{~m}$ in palaeovalley fills; $\mathrm{n}=23, \mathrm{n}=16$ ) are similar with overlapping standard deviations 
Table 2: Summary of sand body thickness, mean storey thickness, mean position of storey contacts (from base of sand body), and storey contact lengths for stacked distributary channels and palaeovalley fills at up-dip locations, down-dip locations, and basin-wide. Note that most sand bodies were not analysed at all locations (see Table 1).

\begin{tabular}{|c|c|c|c|c|c|c|c|}
\hline Interpretation & Basin Location & Metric & $\mathbf{N}$ & Min & Mean & Max & Std. Dev \\
\hline \multirow{12}{*}{$\begin{array}{l}\text { Stacked } \\
\text { distributary } \\
\text { channels }\end{array}$} & \multirow[t]{4}{*}{ Up-dip } & Sand body thickness & 23 & 2.51 & 13.46 & 29.30 & 7.15 \\
\hline & & Mean storey thickness & 33 & 3.00 & 6.96 & 12.50 & 2.29 \\
\hline & & Position of storey & 15 & 2.00 & 3.40 & 14.00 & 3.03 \\
\hline & & Storey contact length & 23 & 23.20 & 69.34 & 167.00 & 41.00 \\
\hline & \multirow[t]{4}{*}{ Down-dip } & Sand body thickness & 16 & 1.54 & 6.01 & 9.51 & 2.56 \\
\hline & & Mean storey thickness & 14 & 1.00 & 5.17 & 6.00 & 2.67 \\
\hline & & Position of storey & 8 & 1.00 & 5.17 & 7.00 & 2.76 \\
\hline & & Storey contact length & 9 & 29.90 & 59.93 & 114.00 & 43.40 \\
\hline & \multirow[t]{4}{*}{ Bulk Trend } & Sand body thickness & 39 & 1.54 & 10.67 & 29.30 & 6.81 \\
\hline & & Mean storey thickness & 47 & 1.00 & 6.76 & 14.50 & 2.35 \\
\hline & & Position of storey & 23 & 1.00 & 5.63 & 14.00 & 3.46 \\
\hline & & Storey contact length & 32 & 23.20 & 65.81 & 167.00 & 41.00 \\
\hline \multirow{12}{*}{$\begin{array}{l}\text { Palaeovalley } \\
\text { fills }\end{array}$} & \multirow[t]{4}{*}{ Up-dip } & Sand body thickness & 12 & 3.29 & 10.46 & 15.30 & 3.68 \\
\hline & & Mean storey thickness & 8 & 1.40 & 6.78 & 10.00 & 3.34 \\
\hline & & Position of storey & 9 & 3.00 & 7.00 & 16.00 & 2.77 \\
\hline & & Storey contact length & 16 & 13.20 & 66.13 & 118.00 & 33.00 \\
\hline & \multirow[t]{4}{*}{ Down-dip } & Sand body thickness & 12 & 5.02 & 13.90 & 24.30 & 7.30 \\
\hline & & Mean storey thickness & 27 & 5.90 & 8.71 & 14.00 & 1.56 \\
\hline & & Position of storey & 11 & 1.00 & 6.75 & 16.00 & 5.30 \\
\hline & & Storey contact length & 29 & 15.50 & 50.95 & 180.00 & 44.40 \\
\hline & \multirow[t]{4}{*}{ Bulk Trend } & Sand body thickness & 24 & 3.29 & 11.84 & 24.30 & 6.75 \\
\hline & & Mean storey thickness & 35 & 1.40 & 6.98 & 13.00 & 3.23 \\
\hline & & Position of storey & 20 & 1.00 & 6.90 & 16.00 & 4.63 \\
\hline & & Storey contact length & 45 & 13.20 & 60.06 & 180.00 & 40.30 \\
\hline
\end{tabular}

(Table 2; Fig. 5). By comparison, in the lower accommodation down-dip domain, stacked distributary sand bodies are markedly thinner than palaeovalleys $(6.0 \mathrm{~m}$ versus $13.9 \mathrm{~m} ; \mathrm{n}=16$, $\mathrm{n}=12)$. As in the up-dip domain, mean storey thickness $(5.2 \mathrm{~m}$ in stacked distributary channels versus $8.7 \mathrm{~m}$ in palaeovalley fills; $\mathrm{n}=14, \mathrm{n}=27$ ), mean position of storey contacts from the base of the sand body $(5.2 \mathrm{~m}$ in stacked distributary channels versus $6.8 \mathrm{~m}$ in palaeovalley fills; $\mathrm{n}=8$, $\mathrm{n}=11)$, and the length of storey contacts $(59.9 \mathrm{~m}$ in stacked distributary channels versus 51.0 $\mathrm{m}$ in palaeovalley fills; $\mathrm{n}=9, \mathrm{n}=29$ ) are similar, with overlapping standard deviations (Table 2 ; Fig. 5). The greater similarity between stacked distributary channel deposits and palaeovalley fills in the up-dip domain reflects proximity to the input point of the fluvial systems into the basin. Therefore, the different basinal processes associated with distributary fluvial systems and valley formation and filling, as discussed below, had little opportunity to partition the two sand body types into two distinct architectures.

\subsection{Stacked distributary channel sand bodies from up-dip to down-dip}

Stacked distributary channel sand bodies become thinner down-system, from $13.5 \mathrm{~m}$ to $6.0 \mathrm{~m}$ on average (maximum $29.3 \mathrm{~m}$ to $15.3 \mathrm{~m}$ ) (over c. $80 \mathrm{~km}$ distance; Fig. 1B). The average storey thickness in these sand bodies decreases from $7.0 \mathrm{~m}$ to $5.17 \mathrm{~m}$. Because sand body thickness decreases at a greater rate than storey thickness, the average number of vertically stacked sand bodies decreases from 1.9 to 1.2 down-dip. The down-dip decrease in average storey thickness could reflect either a real decrease in the depth of the original channel or an increasing amount of storey truncation after deposition. Two additional pieces of data suggest that the downsystem decrease in storey thickness in stacked distributary channels represents a real decrease in the depth of the deposited channel fills: (1) maximum measured storey thickness - the closest approximation to (un-decompacted) bankfull depth of the deepest channels in the system - 
decreases from $12.5 \mathrm{~m}$ up-dip, to $6 \mathrm{~m}$ down-dip; and (2) the down-system increase in the mean position of storey contacts from $3.5 \mathrm{~m}$ to $5.2 \mathrm{~m}$ above the base of the sand body. The latter means that overlying stories are less incised and amalgamated into underlying stories down-dip and that the decrease is storey height is not simply a function of increased top-truncation. These data are consistent with models for distributive fluvial systems in unconfined settings, where increasing frictional interaction of flows with the substrate, and decreasing gradient promote rapid inchannel sedimentation, superelevation of the channel above the flood plain, and channel avulsion (Nichols and Fisher, 2007; Weissmann et al., 2015). Although distributive fluvial system models emphasise the existence of one or few trunk distributaries at any one time (e.g. Weissmann et al., 2010), avulsion is rarely instantaneous, and therefore two or more bifurcating distributaries, each smaller than the upstream trunk, can coexist simultaneously. The recognition of marine or brackish salinity and tidal influence in a minority of channel fills inside the sand bodies of the Pikeville and Hyden formations (e.g. Greb and Chesnut Jr, 1992; Aitken and Flint, 1995; Martino, 1996; Jerrett et al., 2017) is significant to this study, because it implies that the channels may have been within the reach of backwater processes (i.e., influenced by the static standing body of water into which the terminal segment of river empties; e.g., Paola and Mohrig (1996). Theoretical considerations (e.g. Chatanantavet et al., 2012), backed by observational data from modern systems (e.g. Fernandes et al., 2016) show that in unconfined (i.e., deltaic) settings, there is an increased rate of within-channel sedimentation at the transition from normal (gravitationally-driven) fluvial flow to the zone influenced by backwater processes (the upper 0.5 of the backwater length). The high sedimentation and bar construction rates within this zone drives bank erosion, lateral migration and avulsion, leading to the downstream bifurcating plan view morphology of deltas, which bear superficial similarities to distributive fluvial systems. The lower (i.e., downstream) 0.5 of the backwater length is characterised by relatively low within-channel sedimentation rates, which conversely inhibit channel migration and avulsion. Consequently long-occupied channels in fixed positions aggrade vertically. The stratigraphy that results from deposits within the backwater length is a sand body that narrows and thickens downstream (Fernandes et al., 2016). Palaeohydraulic analyses of channel fills from the Pikeville and Hyden formations, undertaken by Jerrett et al. (2017) suggest that these fluvial systems may have had backwater lengths in the order of $40-220 \mathrm{~km}$, but because the contemporaneous shorelines to these fluvial sandstones have not been recognised, it is difficult to have any sense of the position of the transition from normal fluvial flow to backwater influenced. Certainly, the down-system decrease in sand body thickness recorded within stacked distributary channel sand bodies, imply that backwater processes, if present within the study area at all, were less important than continental distributive fluvial processes. The combination of the down-system decrease in sand body and storey thickness, with the decreased number of vertically stacked storeys are a function of decreasing channel depths, and a concomitant decrease in confinement and amalgamation of the original channels that is characteristic of distributive fluvial systems (Davidson et al., 2013; Weissmann et al., 2013).

The lengths of storey contacts inside the sand bodies vary from 69.3/100 m up-dip, to $59.9 / 100 \mathrm{~m}$ down-dip. Storey contacts form as a channel migrates across and erodes into a flood- or delta-plain. Lateral or downstream accreting bars downlap the erosion surface and deposit a channel belt or storey that has a much greater aspect ratio than the channel that formed it Miall (1985); Gibling (2006). Primary factors that influence the length of time, or rate of lateral migration of a channel, that will therefore influence the length of a storey contact include: (a) the channel morphology and fluvial style in which high sinuosity channels typically display higher rates of lateral migration and lower rates of avulsion than low sinuosity channels (Schumm et al., 1996); (b) substrate strength (Stouthamer and Berendsen, 2000; Aslan et al., 2005); and (c) rate of accommodation generation, with higher rates of accommodation promoting vertical aggradation, sedimentation and frequent avulsion (Bridge and Leeder, 1979; Bryant et al., 1995; Blum and Törnqvist, 2000; Slingerland and Smith, 2004; Aslan et al., 2005). The self-similar behaviour of channels dictates that, all other factors being equal, a larger channel will migrate a greater distance before avulsing, and will therefore generate a longer storey 


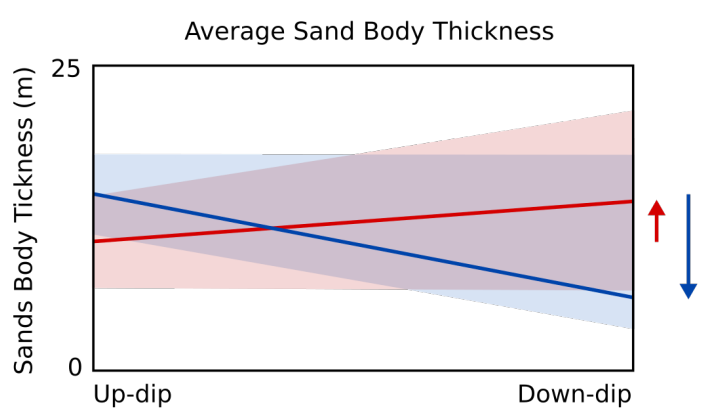

B

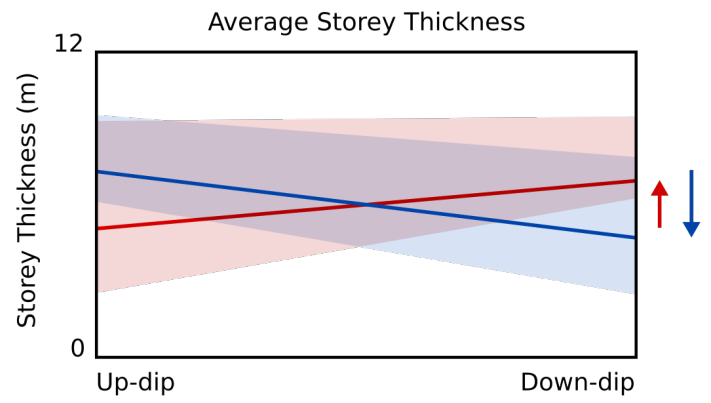

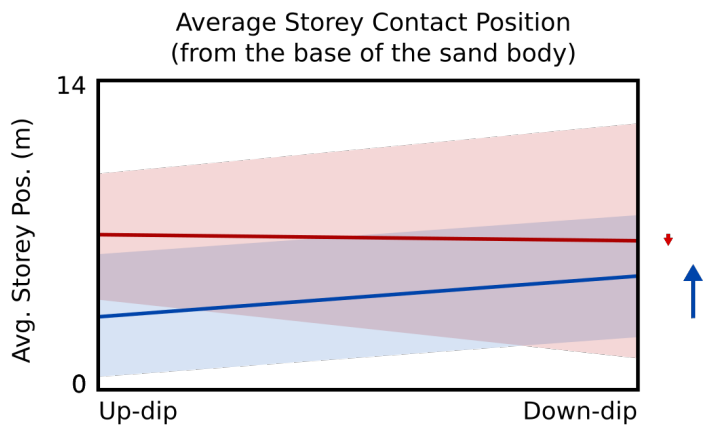

D

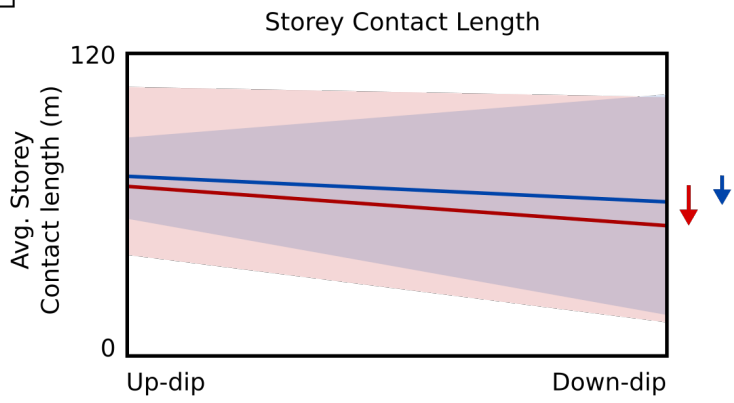

contact (Nanson and Hickin, 1986; Richard et al., 2005). Lengths of preserved storeys are also a function of their truncation during channel amalgamation, with reduced length indicative of greater truncation and storey amalgamation. Although a general decrease down-dip in grain size has been identified in the system (Jerrett et al., 2017), no systematic change in fluvial style down-system has been recognised, which could otherwise influence bank mobility and the lengths of storey contacts. Because this study only takes into account internal storey contacts, the substrate into which all the contacts was eroded was in each case fluvial sand of the underlying sand body. In this foreland basin setting, where fluvial systems prograded from a zone of higher accommodation on the orogenic margin, to a zone of lower accommodation on the cratonic margin, decreasing storey contacts down-system are not consistent with accommodation being the primary control on this metric. Finally, the down-system decrease in the number of vertically stacked channels and increase in vertical aggradation argues for reduced, not increased, downsystem erosion and amalgamation. Therefore, the down-system reduction in storey contact lengths in stacked distributary channels are interpreted to be a function of the down-system decrease in channel size. Overall, the data demonstrate that stacked distributive sand bodies decrease in thickness down-system, primarily driven by a down-system decrease in channel size, consistent with unconfined avulsive processes typical of distributive fluvial systems (Hartley et al., 2010; Davidson et al., 2013). Though the concept, and plan view characteristics of distributive fluvial systems were defined explicitly for fully continental (i.e., non-deltaic) systems (Hartley et al., 2010; Weissmann et al., 2015) the down-system decrease in vertical channel amalgamation and increase in vertical aggradation reflects deconfinemement and radiation of distributary channels away from major entry points into the basin (Nichols and Fisher, 2007; Hartley et al., 2010; Weissmann et al., 2015). Therefore, these architectures would be fully expected in, and the methods of recognising them are exportable to the continental settings envisaged by Hartley et al. (2010) and Weissmann et al. (2015). 

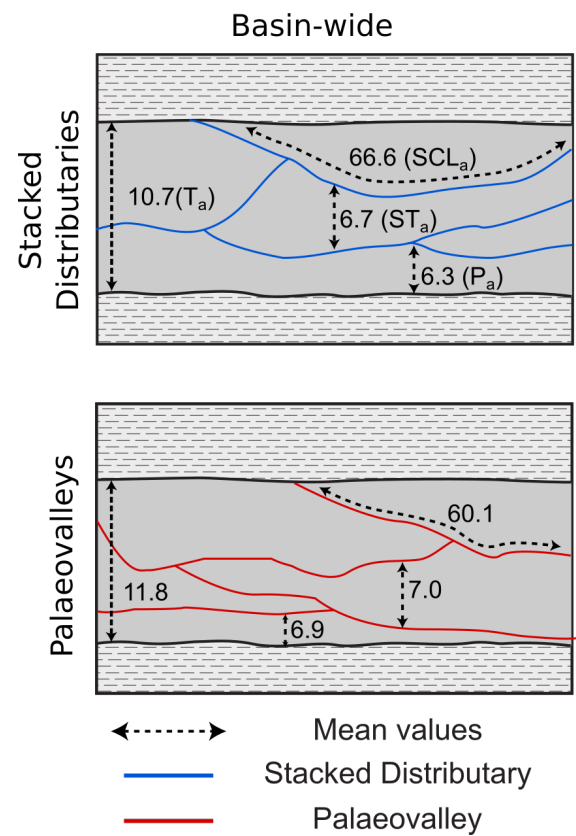

\section{Internal Sand Body Architecture}
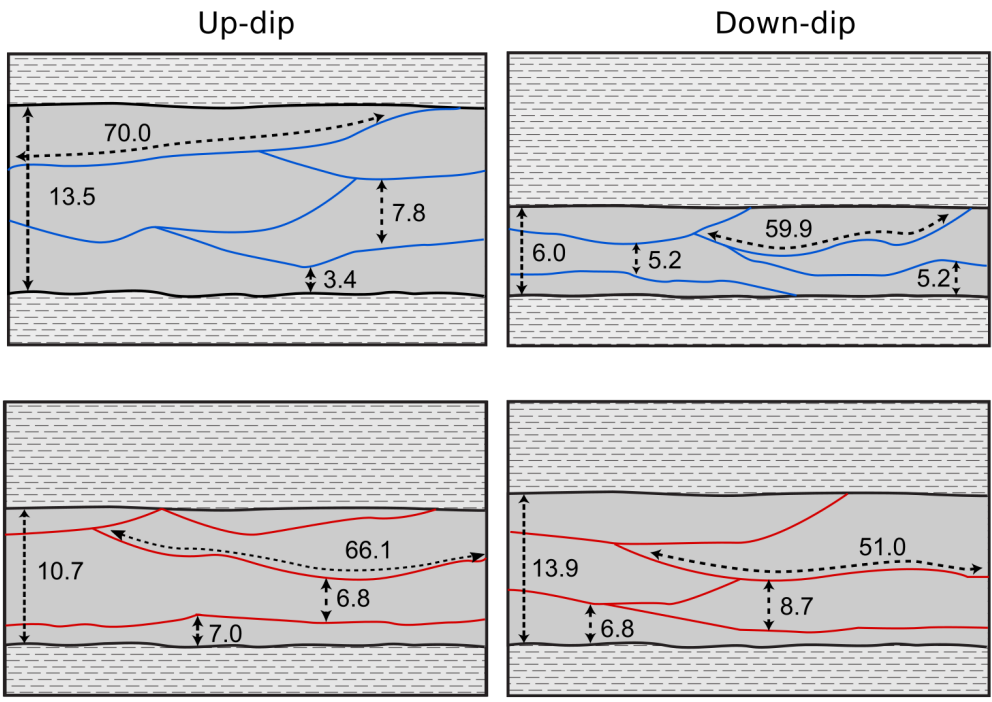

*Schematic sand bodies not to scale*

Figure 6: Schematic illustrating the basin-wide, up-dip and down-dip architectures of stacked distributary channel fill and palaeovalley fill sandstone bodies. Abbreviations: The average sand body thickness (Ta), average storey thickness (STa), average position of storey contact relative to base of sand body (Pa), and average storey contact length (SCLa) are drawn relative to one another. sandstone bodies are not to scale and are only relative to one another.

The down-system increase in bankfull depths in the sand bodies that display a basinward facies shift at their base is wholly compatible with existing models for valley formation and filling. Valleys form in sedimentary basins when an increase in stream power allows the fluvial system to re-entrain previously deposited sediments, or erode into underlying bedrock, as the system adjusts to a new equilibrium surface which is lower than the previous one (Bhattacharya, 2011; Holbrook et al., 2006; Posamentier and Vail, 1988). This increase in stream power is often associated with increased gradient in response to lowered eustatic sea-level or tectonic uplift, but can also occur because of increased discharge and changes in sediment calibre (Blum and Törnqvist, 2000; Holbrook et al., 2006). The change from deposition to erosion is associated with the formation of new geomorphic elements: the development of a tributive fluvial network, headwardly-migrating erosional knickpoints, which can intercept and capture neighbouring fluvial systems (Bhattacharya, 2011; Van Heijst and Postma, 2001; Wescott, 1993). Stream capture, in particular, will increase fluvial discharge down-system, and substantially increase the capacity of the system to erode into the underlying substrata. As discussed by Blum et al. (2013), valley formation is not associated with erosion alone, and terraces of channel belts and associated floodplain strata are typically deposited and preserved within the confines of 
the valley during fluvial incision. Those channel belts deposited during degradational valleyforming phases should display storey thicknesses that increase down-system. Palaeovalley fills include also the deposits within the valley that are formed during subsequent aggradational back-filling, this time as a response to decreasing fluvial power and capacity of the system to transport and erode sediment. The antecedent tributive network of streams generated during degradation and initial valley formation will persist (and continue to erode) until the entirety of the accommodation excess in the valley is filled (Blum et al., 2013). Hence, channel belts deposited during the aggradational valley healing phase will also display storey thicknesses that increase down-system.

The increase in the number of stacked stories, and channel fill amalgamation is likely a function of the tectonic setting of these transverse palaeovalley sand bodies in the central Appalachian foreland basin. In foreland basins, there is a higher rate of tectonic subsidence towards the orogenic margin, compared to the cratonic margin. Consequently, during palaeovalley formation, the higher rates of tectonic accommodation in the up-dip, orogenic margin will suppress the degree of erosion and amalgamation into underlying deposits. Towards the cratonic margin, a lower rate of tectonic accommodation will promote truncation and amalgamation of the channel fills as the fluvial system cuts and fills the valley (Jerrett et al., 2017). This architectural motif in the palaeovalleys of the Pikeville and Hyden formations - increased truncation and amalgamation down-system - is likely more characteristic of the tectonic setting, rather than inherent to palaeovalley systems in general (cf., passive margins where accommodation increases down-system).

At first glance, the down-dip decrease in the mean lengths of storey contacts in palaeovalley fills from $66.1 \mathrm{~m}$ to $51.0 \mathrm{~m}$ is counter-intuitive, given that down-system decreases in lengths of storey contacts in stacked distributary channel deposits were ascribed to decreasing channel size. This decrease may be related to a down-system increase in confinement of the channels within more mature palaeovalleys, which inhibited lateral accretion, and formation of long storey contacts.

\section{Conclusions}

This study demonstrates that stacked distributary channels and palaeovalley fills exhibit different basin-scale architectures. These differences can be difficult to identify from outcrop data, especially close to the input point of fluvial systems into the sedimentary basin. The principal control on stacked distributary channel architecture is the regional down-system avulsion behaviour and reduction in confinement of distributive fluvial systems, which result in down-system decreases in channel size and channel amalgamation. This in turn results in sand bodies that thin down system, storeys that reduce in thickness, storey contacts that increase in their positions in the sand body, and storey contacts that reduce in length. The principal control on palaeovalley fill architecture is the down-system tributive nature of the fluvial systems that deposit during both the degradational valley-forming phase, and aggradational valley-filling phase. Channels increase in size down-dip, resulting in sand bodies and storeys that thicken down-system. A secondary control on palaeovalley architecture is the regional accommodation profile. In the Central Appalachian Basin, a down-system decrease in tectonic accommodation, from the orogenic margin towards the foreland resulted in increased channel amalgamation down-system, with the effect of reducing the mean position of storey contacts inside the resulting sand bodies. This tectonic control would be likely reversed in passive margin basins, where accommodation increases down the fluvial system. Regional accommodation is a strong influence on the architectures of both stacked distributary channels and palaeovalleys in other basin settings, so the results of this study should not be universally applied without consideration of basin setting and the scale of the fluvial systems operating in the basin. Another consideration influencing down-system stratal architectures will be the possible influence of backwater processes where fluvial systems enter lakes or the sea. 


\section{Acknowledgements}

458

459 The authors thank and acknowledge Total S.A. for funding the research that lead to the presented

460 work. The authors would like to further thank Georgina Heldreich and Rachel Harding for

461 providing useful comments on an early draft of the manuscript. Finally the authors kindly and

462 appreciatively thank and acknowledge Janok Bhattacharya and an anonymous reviewer, and

463 Chief Editor Jasper Knight for their constructive reviews and feedback 


\section{References}

Aitken, J. F. and Flint, S. S. (1994). High-Frequency Sequences and the Nature of Incised-Valley Fills in Fluvial Systems of the Breathitt Group (Pennsylvanian), Appalachian Foreland Basin, Eastern Kentucky.

Aitken, J. F. and Flint, S. S. (1995). The application of high-resolution sequence stratigraphy to fluvial systems: a case study from the upper carboniferous breathitt group, eastern kentucky, usa. Sedimentology, 42(1):3-30.

Aslan, A., Autin, W. J., and Blum, M. D. (2005). Causes of river avulsion: insights from the late holocene avulsion history of the mississippi river, usa. Journal of Sedimentary Research, $75(4): 650-664$.

Bellian, J. A., Kerans, C., and Jennette, D. C. (2005). Digital outcrop models: applications of terrestrial scanning lidar technology in stratigraphic modeling. Journal of sedimentary research, $75(2): 166-176$.

Bhattacharya, J. P. (2011). Practical problems in the application of the sequence stratigraphic method and key surfaces: integrating observations from ancient fluvial-deltaic wedges with quaternary and modelling studies. Sedimentology, 58(1):120-169.

Blum, M., Martin, J., Milliken, K., and Garvin, M. (2013). Paleovalley systems: insights from quaternary analogs and experiments. Earth-Science Reviews, 116:128-169.

Blum, M. D. and Törnqvist, T. E. (2000). Fluvial responses to climate and sea-level change: a review and look forward. Sedimentology, 47:2-48.

Bridge, J. S. and Leeder, M. R. (1979). A simulation model of alluvial stratigraphy. Sedimentology, 26(5):617-644.

Bridge, J. S. and Tye, R. S. (2000). Interpreting the dimensions of ancient fluvial channel bars, channels, and channel belts from wireline-logs and cores. AAPG bulletin, 84(8):1205-1228.

Bryant, M., Falk, P., and Paola, C. (1995). Experimental study of avulsion frequency and rate of deposition. Geology, 23(4):365-368.

Buckley, S. J., Howell, J., Enge, H., and Kurz, T. (2008). Terrestrial laser scanning in geology: data acquisition, processing and accuracy considerations. Journal of the Geological Society, $165(3): 625-638$.

Burnham, B. S. and Hodgetts, D. (2019). Quantifying spatial and architectural relationships from fluvial outcrops. Geosphere, 15(1):236-253.

Chatanantavet, P., Lamb, M. P., and Nittrouer, J. A. (2012). Backwater controls of avulsion location on deltas. Geophysical Research Letters, 39(1).

Chesnut Jr, D. R. (1994). Eustatic and tectonic control of deposition of the lower and middle pennsylvanian strata of the central appalachian basin.

Davidson, S. K., Hartley, A. J., Weissmann, G. S., Nichols, G. J., and Scuderi, L. A. (2013). Geomorphic elements on modern distributive fluvial systems. Geomorphology, 180:82-95.

Fabuel-Perez, I., Hodgetts, D., and Redfern, J. (2010). Integration of digital outcrop models (doms) and high resolution sedimentology-workflow and implications for geological modelling: Oukaimeden sandstone formation, high atlas (morocco). Petroleum Geoscience, 16(2):133154. 
Fernandes, A. M., Törnqvist, T. E., Straub, K. M., and Mohrig, D. (2016). Connecting the backwater hydraulics of coastal rivers to fluvio-deltaic sedimentology and stratigraphy. Geology, 44(12):979-982.

Friend, P., Slater, M., and Williams, R. (1979). Vertical and lateral building of river sandstone bodies, ebro basin, spain. Journal of the Geological Society, 136(1):39-46.

Gibling, M. R. (2006). Width and thickness of fluvial channel bodies and valley fills in the geological record: a literature compilation and classification. Journal of sedimentary Research, 76(5):731-770.

Gradstein, F. M., Ogg, J. G., Schmitz, M., and Ogg, G. (2012). The geologic time scale 2012. Elsevier.

Greb, S. F. and Chesnut Jr, D. R. (1992). Transgressive channel filling in the breathitt formation (upper carboniferous), eastern kentucky coal field, usa. Sedimentary geology, 75(3-4):209-221.

Greb, S. F., Pashin, J. C., Martino, R. L., and Eble, C. F. (2008). Appalachian sedimentary cycles during the pennsylvanian: Changing influences of sea level, climate, and tectonics. Resolving the Late Paleozoic Ice Age in Time and Space, 441:235.

Hampson, G., Davies, S., Elliott, T., Flint, S., and Stollhofen, H. (1999). Incised valley fill sandstone bodies in upper carboniferous fluvio-deltaic strata: recognition and reservoir characterization of southern north sea analogues. In Geological Society, London, Petroleum Geology Conference series, volume 5, pages 771-788. Geological Society of London.

Hartley, A. J., Weissmann, G. S., Nichols, G. J., and Warwick, G. L. (2010). Large distributive fluvial systems: characteristics, distribution, and controls on development. Journal of Sedimentary Research, 80(2):167-183.

Hirst, J. (1992). Variations in alluvial architecture across the oligo-miocene huesca fluvial system, ebro basin, spain.

Hodgetts, D. (2013). Laser scanning and digital outcrop geology in the petroleum industry: A review. Marine and Petroleum Geology, 46:335-354.

Hodgetts, D., Gawthorpe, R., Wilson, P., and Rarity, F. (2007). Integrating digital and traditional field techniques using virtual reality geological studio (vrgs). In 69th EAGE Conference and Exhibition incorporating SPE EUROPEC $200 \%$.

Holbrook, J., Scott, R. W., and Oboh-Ikuenobe, F. E. (2006). Base-level buffers and buttresses: a model for upstream versus downstream control on fluvial geometry and architecture within sequences. Journal of Sedimentary Research, 76(1):162-174.

Holbrook, J. M. and Bhattacharya, J. P. (2012). Reappraisal of the sequence boundary in time and space: case and considerations for an su (subaerial unconformity) that is not a sediment bypass surface, a time barrier, or an unconformity. Earth-Science Reviews, 113(3-4):271-302.

Horne, J., Ferm, J., Caruccio, F., and Baganz, B. (1978). Depositional models in coal exploration and mine planning in appalachian region. AAPG bulletin, 62(12):2379-2411.

Jennette, D. C., Jones, C. R., Van Wagoner, J. C., and Larsen, J. E. (1991). High-resolution sequence stratigraphy of the upper cretaceous tocito sandstone: the relationship between incised valleys and hydrocarbon accumulation, san juan basin, new mexico.

Jerrett, R. M., Flint, S. S., and Brunt, R. L. (2017). Palaeovalleys in foreland ramp settings: what happens as accommodation decreases down dip? Basin Research, 29(6):747-774. 
Kukulski, R. B., Hubbard, S. M., Moslow, T. F., and Raines, M. K. (2013). Basin-scale stratigraphic architecture of upstream fluvial deposits: Jurassic-cretaceous foredeep, alberta basin, canada. Journal of Sedimentary Research, 83(8):704-722.

Martino, R. (1996). Stratigraphy and depositional environments of the kanawha formation (middle pennsylvanian), southern west virginia, usa. International Journal of Coal Geology, $31(1-4): 217-248$.

Miall, A. D. (1985). Architectural-element analysis: a new method of facies analysis applied to fluvial deposits. Earth-Science Reviews, 22(4):261-308.

Nanson, G. C. and Hickin, E. J. (1986). A statistical analysis of bank erosion and channel migration in western canada. Geological Society of America Bulletin, 97(4):497-504.

Nichols, G. and Fisher, J. (2007). Processes, facies and architecture of fluvial distributary system deposits. Sedimentary geology, 195(1-2):75-90.

Olariu, M. I., Aiken, C., Bhattacharya, J., and Xu, X. (2011). Interpretation of channelized architecture using three-dimensional photo real models, pennsylvanian deep-water deposits at big rock quarry, arkansas. Marine and Petroleum Geology, 28(6):1157-1170.

Owen, A., Nichols, G. J., Hartley, A. J., Weissmann, G. S., and Scuderi, L. A. (2015). Quantification of a distributive fluvial system: the salt wash dfs of the morrison formation, sw usa. Journal of Sedimentary Research, 85(5):544-561.

Paola, C. and Mohrig, D. (1996). Palaeohydraulics revisited: Palaeoslope estimation in coarsegrained braided rivers. Basin Research, 8(3):243-254.

Posamentier, H. and Vail, P. (1988). Eustatic controls on clastic deposition ii-sequence and systems tract models.

Posamentier, H. W. and Allen, G. P. (1993). Variability of the sequence stratigraphic model: effects of local basin factors. Sedimentary geology, 86(1-2):91-109.

Pringle, J., Howell, J., Hodgetts, D., Westerman, A., and Hodgson, D. (2006). Virtual outcrop models of petroleum reservoir analogues: a review of the current state-of-the-art. First break, $24(3): 33-42$.

Pringle, J., Westerman, A., Clark, J., Drinkwater, N., and Gardiner, A. (2004). 3d highresolution digital models of outcrop analogue study sites to constrain reservoir model uncertainty: an example from alport castles, derbyshire, uk. Petroleum Geoscience, 10(4):343-352.

Quinlan, G. M. and Beaumont, C. (1984). Appalachian thrusting, lithospheric flexure, and the paleozoic stratigraphy of the eastern interior of north america. Canadian Journal of Earth Sciences, 21(9):973-996.

Rarity, F., Van Lanen, X., Hodgetts, D., Gawthorpe, R., Wilson, P., Fabuel-Perez, I., and Redfern, J. (2014). Lidar-based digital outcrops for sedimentological analysis: workflows and techniques. Geological Society, London, Special Publications, 387(1):153-183.

Rice, C. L. and Hiett, J. K. (1994). Revised correlation chart of coal beds, coal zones, and key stratigraphic units in the pennsylvanian rocks of eastern kentucky. Technical report, US Geological Survey.

Richard, G. A., Julien, P. Y., and Baird, D. C. (2005). Statistical analysis of lateral migration of the rio grande, new mexico. Geomorphology, 71(1-2):139-155.

Slingerland, R. and Smith, N. D. (2004). River avulsions and their deposits. Annu. Rev. Earth Planet. Sci., 32:257-285. 
Stouthamer, E. and Berendsen, H. J. (2000). Factors controlling the holocene avulsion history of the rhine-meuse delta (the netherlands). Journal of Sedimentary Research, 70(5):1051-1064.

Tankard, A. J. (1986). Depositional response to foreland deformation in the carboniferous of eastern kentucky. AAPG Bulletin, 70(7):853-868.

Thomas, W. A. (1976). Evolution of ouachita-appalachian continental margin. The Journal of Geology, 84(3):323-342.

Van Heijst, M. and Postma, G. (2001). Fluvial response to sea-level changes: a quantitative analogue, experimental approach. Basin Research, 13(3):269-292.

van Lanen, X. M., Hodgetts, D., Redfern, J., and Fabuel-Perez, I. (2009). Applications of digital outcrop models: two fluvial case studies from the triassic wolfville fm., canada and oukaimeden sandstone fm., morocco. Geological Journal, 44(6):742-760.

Van Wagoner, J., Posamentier, H., Mitchum, R., Vail, P., Sarg, J., Loutit, T., and Hardenbol, J. (1988). An overview of the fundamentals of sequence stratigraphy and key definitions.

Van Wagoner, J. C., Mitchum, R., Campion, K., and Rahmanian, V. (1990). Siliciclastic sequence stratigraphy in well logs, cores, and outcrops: concepts for high-resolution correlation of time and facies.

Weissmann, G., Hartley, A., Nichols, G., Scuderi, L., Olson, M., Buehler, H., and Banteah, R. (2010). Fluvial form in modern continental sedimentary basins: distributive fluvial systems. Geology, 38(1):39-42.

Weissmann, G., Hartley, A., Scuderi, L., Nichols, G., Davidson, S., Owen, A., Atchley, S., Bhattacharyya, P., Chakraborty, T., Ghosh, P., et al. (2013). Prograding distributive fluvial systems: geomorphic models and ancient examples. New Frontiers in Paleopedology and Terrestrial Paleoclimatology: SEPM, Special Publication, 104:131-147.

Weissmann, G., Hartley, A. J., Scuderi, L., Nichols, G., Owen, A., Wright, S., Felicia, A., Holland, F., and Anaya, F. (2015). Fluvial geomorphic elements in modern sedimentary basins and their potential preservation in the rock record: a review. Geomorphology, 250:187-219.

Wescott, W. (1993). Geomorphic thresholds and response of fluvial systems - implications for sequence stratigraphy. AAPG Bulletin, 77:1208-1218.

Wu, C. and Bhattacharya, J. (2015). Paleohydrology and 3d facies architecture of ancient point bars, ferron sandstone, notom delta, south-central utah. Journal of, Sedimentary Research, 85:399-418. 